MATERNAL SENSITIVITY AND LATENCY TO POSITIVE EMOTION FOLLOWING CHALLENGE: PATHWAYS THROUGH EFFORTFUL CONTROL

\author{
ANNE CONWAY \\ Columbia University \\ SUSAN C. MCDONOUGH \\ University of Michigan \\ MICHAEL MACKENZIE \\ Columbia University \\ ALISON MILLER \\ University of Michigan \\ CAROLYN DAYTON \\ Wayne State University
}

\author{
KATHERINE ROSENBLUM, MARIA MUZIK, AND ARNOLD SAMEROFF \\ University of Michigan
}

ABSTRACT: The ability to self-generate positive emotions is an important component of emotion regulation. In this study, we focus on children's latency to express positive emotions following challenging situations and assess whether this ability operates through early maternal sensitivity and children's effortful control. Longitudinal relations between maternal sensitivity, infant negative affect, effortful control, and latency to positive emotion following challenge were examined in 156 children who were 33 months of age. Structural equation models supported the hypothesis that maternal sensitivity during infancy predicted better effortful control and, in turn, shorter latencies to positive emotions following challenge at 33 months. Directions for future research are discussed.

RESUMEN: La habilidad para autogenerar emociones positivas es un componente importante de la regulación de la emoción. En este estudio, nos enfocamos en el estado latente de los niños para expresar emociones positivas después de situaciones desafiantes y evaluar si esta habilidad opera a través de la temprana sensibilidad maternal y el esforzado control de los niños. Se examinaron las relaciones longitudinales entre la sensibilidad maternal, el efecto negativo del infante, el control esforzado, y el estado latente hacia la emoción positiva después de situaciones desafiantes, en 156 niños de 33 meses. Los modelos de ecuación estructural apoyaron la hipótesis de que la sensibilidad maternal durante la infancia predijo un mejor control esforzado y, a la vuelta, los más cortos estados latentes hacia emociones positivas después de situaciones desafiantes a los 33 meses. Se discuten las directrices para la investigación futura.

RÉSUMÉ: La capacité à auto-générer des émotions positives est une composante importante de la régulation des émotions. Dans cette étude nous nous concentrons sur la latence des enfants à exprimer des émotions positives après des situations difficiles et nous évaluons si cette capacité opère à travers une sensibilité maternelle précoce et le contrôle fait avec effort des enfants. Les relations longitudinales entre la sensibilité maternelle, l'affect négatif du nourrisson, le contrôle fait avec effort et la latence et l'émotion positive après des difficultés ont été examinés chez 156 enfants de 33 mois. Des modèles d'équation structurelle ont soutenu l'hypothèse selon laquelle la sensibilité maternelle durant la petite enfance prédisait un meilleur contrôle avec effort et ensuite des latences plus courtes vers des émotions positives après des difficultés à 33 mois. Des directions pour des recherches à venir sont discutées.

This research was supported by Grant MH 54322 from the National Institute of Mental Health awarded to SCM. We thank the families who participated in the Michigan Family Study and the staff who helped with data gathering and videotape coding.

Direct correspondence to: Anne Conway, Columbia University, 1255 Amsterdam Avenue 710, New York, NY 10027; e-mail: ac3292@ columbia.edu.

Infant Mental Health Journal, Vol. 35(3), 274-284 (2014)

(c) 2014 Michigan Association for Infant Mental Health

View this article online at wileyonlinelibrary.com.

DOI: 10.1002/imhj.21445 
ZUSAMMENFASSUNG: Die Fähigkeit, positive Emotionen selbst zu erzeugen, ist ein wichtiger Bestandteil der Emotionsregulation. In dieser Studie fokussieren wir auf die Latenzzeit von Kindern, positive Emotionen nach herausfordernden Situationen zu zeigen, und beurteilen, ob diese Fähigkeit durch frühe mütterliche Feinfühligkeit und bewusste Kontrolle der Kinder beeinflusst wird. Longitudinale Beziehungen zwischen mütterlicher Feinfühligkeit, dem negativen Affekt des Säuglings, bewusster Kontrolle und der Latenzzeit hinichtlich positiver Emotionen nach einer Herausforderung wurden bei 156 Kindern im Alter von 33 Monaten untersucht. Strukturgleichungsmodelle unterstützten die Hypothese, dass die Feinfühligkeit der Mütter während des Säuglingsalters eine bewusstere Kontrolle und wiederum kürzere Latenzzeiten für positive Emotionen nach einer Herausforderung im Alter von 33 Monaten voraussagen konnte. Hinweise für die zukünftige Forschung werden diskutiert.

ABSTRACT: The ability to self-generate positive emotions is an important component of emotion regulation. In this study, we focus on children's latency to express positive emotions following challenging situations and assess whether this ability operates through early maternal sensitivity and children's effortful control.

抄録:ポジティブな情緒を自己生成する能力ability to self-generate positive emotionsは、情緒調節の重要な構成要素である。この研究で、 私たちは困難な状況の後に、子どもがポジティブな情緒を表出するまでの潜伏時間に焦点付け、この能力が早期の母親の感受性と子ど もの努力したコントロールを通して作用するかどうかを評価する。母親の感受性、乳児のネガティブな感情、努力したコントロール、 および困難後のポジティブな情緒表出潜時の縦断的な関係が、156人の33か月児について調査された。構造方程式モデルによって、乳 児期の母親の感受性が、33か月時のより良い努力したコントロールと、次に、より短い困難後のポジティブな情緒表出潜時を予測する という仮説が支持された。

The ability to flexibly adapt and self-generate positive emotions following challenge and changing contexts is an important aspect of emotion regulation. Within early childhood, this has been demonstrated in a number of studies. For example, generating positive emotions following challenge has been reflected in infants' ability to resume playful interactions following physical and emotional separation from caregivers in the Strange Situation and Still-Face paradigms (Haley \& Stansbury, 2003; Kogan \& Carter, 1996; Rosenblum, McDonough, Muzik, Miller, \& Sameroff, 2002; Thompson \& Lamb, 1984; Weinberg \& Tronick, 1996). This also has been demonstrated by young children's ability to self-generate positive emotions following disappointment, which has been associated with low levels of behavior problems (Cole, Zahn-Waxler, \& Smith, 1994).

Changing contexts require children to easily transition and flexibly adapt their behavior and expressions of emotions to be in concert with new contextual demands. For example, as an indicator of regulation, Clark, Woodward, Horward, and Moor (2008) assessed the quality of preschool children's transitions between problem-solving tasks and how smoothly children moved from one task to another or refused to transition across tasks. The ability to modify behavior as a function of the demand characteristics of an environmental context (i.e., ego-resiliency; Block \& Block, 1980) also has been examined and has been found to be associated with competence and low levels of internalizing behaviors (Eisenberg et al., 1997; Eisenberg et al., 2004).

In sum, children's ability to flexibly adapt and generate positive emotions following challenge and changing contexts has been identified as an important aspect of emotion regulation and better functioning. Little attention, however, has been given to identifying early antecedents and processes related to this ability. Therefore, in this study, we address this gap by examining early predictors and mechanisms that may underlie the ability to generate positive emo- tions following challenge and changing contexts-a component of emotion regulation.

\section{DEVELOPMENT OF EMOTION REGULATION}

Emotion regulation develops in the context of early caregiverinfant interactions (Field, 1994). Theory and research have suggested that the development of emotion regulation is based on caregivers' sensitivity and the infants' negative affect (Calkins, 1994; Kopp, 1989; Mangelsdorf, Shapiro, \& Marzoff, 1995; Nachmias, Gunnar, Mangelsdorf, Parritz, \& Buss, 1996). High levels of sensitive caregiving and low levels of negative affect are expected to predict emotion regulation. Although infants may attempt to regulate their emotions through withdrawal and selfstimulating behaviors, they may have difficultly in independently regulating their emotions because their systems are not sufficiently developed. Therefore, infants are dependent on external supports to help them regulate their emotions.

Studies examining early predictors of emotion regulation have reported that maternal sensitivity is associated with emotion regulation in infancy (Cohn \& Tronick, 1983; Field, 1981; Gable \& Isabella, 1992; Stifter \& Moyer, 1991), and warm, accepting parenting control has been found to be associated with emotion regulation in preschoolers (Gilliom, Shaw, Beck, Schonberg, \& Lukon, 2002). Conversely, higher levels of infant negative reactivity have been found to predict lower levels of regulation (Braungart-Rieker \& Stifter, 1996). In the context of maternal sensitivity, however, infants with high negative reactivity have been found to demonstrated less emotion dysregulation during preschool (Leerkes, Blankson, \& O'Brien, 2009).

Significantly less attention has been placed on predictors of children's expressions of positive emotions, particularly following challenge. In related studies, maternal sensitivity has been 
found to be associated with concurrent ratings of infant emotion regulation following the Still-Face challenge (Braungart-Rieker, Garwood, Powers, \& Notaro, 1998; Kogan \& Carter, 1996; Rosenblum, et al., 2002), and secure attachment at 18 months predicted higher ratings of ego-resiliency at 4.5 years (e.g., flexible adaption across changing contexts) (Arend, Gove, \& Sroufe, 1979). Therefore, it is possible that the extent to which mothers demonstrate sensitivity during play in infancy, along with lower levels of infant negative affect, may forecast the long-term ability to self-generate positive emotions following challenge during early childhood. It also is possible that this may operate through children's effortful or "willful" control (EC).

\section{EC}

EC refers to the ability to inhibit a dominant response to perform a subdominant response (Rothbart, 1989). It consists of the regulatory (vs. reactive) components of temperament and regulates children's reactive and impulsive behaviors. EC undergoes dramatic growth during the third year of life, particularly around 30 months, and develops at different rates for children (Rothbart, Ellis, Rueda, \& Posner, 2003). During this time, executive attentional abilities, located in the anterior attention network, begin to grow dramatically and take over the control of attention, facilitating the development of EC.

As such, EC includes components such as attentional and behavioral persistence. The ability to focus attention and inhibit impulses to persist on challenging tasks has been extensively used in studies of EC and self-control (Dennis, 2006; Drake, Belsky, \& Fearon, 2013; Taylor, Eisenberg, Spinrad, \& Widaman, 2013). In previous research by Liew et al. (2003), observational measures of attentional and behavioral persistence during challenging tasks were positively associated with additional indices of EC and negatively correlated with externalizing behaviors (Eisenberg et al., 2004). Therefore, observed EC measures such as behavioral persistence are associated with children's socioemotional development and also may be associated with their ability to generate positive emotions following challenge.

This is consistent with theory. According to Posner and Rothbart (2000), attentional abilities underlie emotion regulation, and the development of the attention system facilitates increased ability to regulate emotions. Likewise, Rothbart and Posner (2006) suggested that EC is an important mechanism underlying the ability to flexibly adapt across changing contexts (i.e., ego-resiliency). Based on theory and existing evidence for relations between EC and emotion regulation (Posner \& Rothbart, 2000), we propose that EC may underlie the ability to self-generate positive emotions following challenge. Supporting evidence includes reports that $\mathrm{EC}$ has been found to be associated with emotion regulation as assessed by the ability to express positive emotions following disappointment (Kieras, Tobin, Graziano, \& Rothbart, 2005; Simonds, Kieras, Rueda, \& Rothbart, 2007). Specifically, children between the ages of 3 and 5 years who scored higher on EC and children between the ages of 7 and 10 years who had high levels of executive attention self-generated more positive emotion following the receipt of both desirable and undesirable gifts (Kieras et al., 2005; Simonds et al., 2007). It is not clear, however, whether $\mathrm{EC}$ is associated with generating positive emotions following challenge at 33 months. We address this gap by examining whether EC is associated with shorter latencies to positive emotion following challenge. We also examine whether EC mediates the longitudinal relations between early predictors and the ability to self-generate positive emotions following challenge. These early predictors may include maternal sensitivity and infant negative affect.

\section{PREDICTORS OF EFFORTFUL CONTROL}

Theorists have long proposed the role of the environment and social relations in the development of higher order control skills. For example, Vygtosky (1981) proposed that higher order skills reflect voluntary versus reactive abilities, and with the help of others, individuals can learn to inhibit automatic responses and voluntarily select alternative behaviors. Accordingly, it was in the joint socially mediated interaction space and support where alternative strategies could develop (Vygotsky, 1981).

Although EC is hypothesized to have a genetic component, contemporary theorists have proposed that EC develops from an interplay between temperamental characteristics and environmental experiences (Posner \& Rothbart, 2000). One of these includes parenting, which appears to make significant contributions and shape its development (Goldmsith, Buss, \& Lemery, 1997; Kopp, 1989, 1992; Rothbart \& Bates, 2006).

A number of investigators have documented relations between maternal sensitivity and maternal attention support and children's long-term EC in preschool and elementary school (Graziano, Keane, \& Calkins, 2010; Kochanska, Murray, \& Harlan, 2000; Olson, Bates, Sandy, \& Schilling, 2002; Spinrad et al., 2012). For example, Kochanska et al. (2000) noted that maternal responsiveness at 22 months and infant sustained attention at 9 months were positively related to EC at 22 and 33 months. Parental verbal stimulation, along with warm, positive, responsive, and contingent parenting, also has been found to longitudinally predict inhibitory control (Kochanska, Murray, \& Harlan, 2000; Li-Grining, 2007; Olson, Bates, \& Bayles, 1990) whereas negative controlling behaviors such as power-assertive behaviors and taking over tasks for children have been found to predict poorer delay inhibition (Silverman \& Ragusa, 1990). Furthermore, in studies utilizing data from the National Institute of Child Health and Human Development (NICHD) Early Child Care Research Network (1998), sensitivity across the first 3 years predicted children's EC, specifically the ability to voluntarily control and resist temptation at 2 and 3 years. If mothers have engaged in more attention-redirecting behaviors during problem-solving tasks, however, temperamentally inhibited toddlers have been found to demonstrate lower levels of EC-related variables (e.g., delay inhibition) at preschool. In sum, existing data underscore contributions of maternal sensitivity and child temperament in the prediction of EC. 
Recently, Taylor et al. (2013) examined prospective relations between maternal behaviors, EC, and ego-resiliency. Findings from their study revealed significant indirect effects of EC in mediating relations between early parenting and children's subsequent egoresiliency. Specifically, maternal intrusive parenting at 18 months negatively predicted EC at 30 months; this in turn predicted lower levels of ego-resiliency at preschool. Their study has provided new findings on the important role that EC plays in the relations between early parenting and preschool resiliency outcomes. Little is known, however, about whether EC also serves as an important pathway during early childhood in the relations between early maternal sensitivity and subsequent latency to positive emotions following challenge. Whereas maternal intrusiveness may provide a context that is associated with lower levels of EC, maternal sensitivity may provide a context that facilitates the growth and development of early emerging EC abilities. These assets, in turn, may be capitalized on to facilitate flexible adaptations across transitions and, specifically, shorter latencies to express positive emotions following challenge.

\section{STUDY GOALS}

Based on existing theory and research, we hypothesize that EC will mediate relations between maternal sensitivity and infant negative affect at 7 months and latency to positive emotions at 33 months. Specifically, we hypothesize that higher levels of maternal sensitivity and lower levels of infant negative affect at 7 months will predict shorter latencies to positive emotions following challenge at 33 months, and that these effects will work through higher levels of EC.

\section{METHOD}

\section{Participants}

One hundred fifty-six children and their mothers from the United States enrolled in the study (McDonough, 1994). Mothers and infants were recruited from pediatric clinics and assessed when the infants were 7 months old. Fifty-seven percent of the infants were female, and $43 \%$ were male. Eighty percent were Caucasian; $20 \%$ were classified as non-Caucasian. Twenty-eight percent were enrolled in childcare at 7 months. Average age for mothers was 30 (range $=16-43$ ) years. Thirty-eight percent of mothers had less than a bachelor's degree; $62 \%$ had a bachelor's degree or above. The median annual family income at 7 months was between $\$ 55,000$ and 59,999 (interquartile range $=\$ 35,000-79,999$ ). Eighty-six percent of the mothers were married, $5 \%$ were living with a partner, and $9 \%$ were single or divorced. Attrition analyses revealed no significant differences between study participants and those who dropped out on child gender, race, enrollment in childcare, and mother's marital status. Significant differences were revealed, however, for maternal age, $p<.05$, and family income, $p<.05$, with older ages and greater income for study participants versus those who dropped out.

\section{7-Month Procedure}

Maternal interview and mother-infant interaction. At 7 months of age, infants and their mothers were visited at home by a trained graduate student. Demographic information was collected during an interview. One week later, mothers and infants participated in a series of free-play and structured teaching tasks in the laboratory (Crowell \& Feldman, 1988) along with the Still-Face procedure (Tronick \& Weinberg, 1992).

Maternal sensitivity in the laboratory. The extent to which mothers were infant-centered (e.g., follow cues, gently soothe, acknowledge infant state, use appropriate pacing, soft tone) was rated on a scale of 0 (none) to 3 (high).

Infant affect in the laboratory. Trained research assistants rated the frequency and intensity of positive (e.g., cooing, smiling, laughing) affect during the free-play task, the teaching task, and the Still-Face episode. Infant negative affect (e.g., fussing, crying, screaming) also was rated on a scale of 0 (none) to 3 (high) during the freeplay task, the teaching task, and the free-play interaction task in the high chair during the Still-Face episode (Miller, McDonough, Rosenblum, \& Sameroff, 2002). Weighted kappa values for maternal sensitivity, infant negative affect, and infant positive affect were $.71, .83$, and .87 , respectively.

\section{3-Month Protocol}

Maternal interview and mother-child interaction. When children were 33 months old, they were visited at home by a trained graduate student. Demographic information was collected during an interview with the mother. One week later, mothers and children participated in a series of interaction tasks at the laboratory based on the goodness-of-fit protocol (Seifer, Dickstein, Parade, Hayden, Magee, \& Schiller, 2014). These included a free-play task, cleanup tasks, empathy tasks, two teaching tasks, two challenge tasks, and two problem-solving tasks.

Emotion-induction tasks. Mothers were asked to leave the room and observe through a one-way mirror while children participated in four tasks used to induce anger and joy in children (Laboratory Temperament Assessment Battery: Preschool Version; Goldsmith, Reilly, Lemery, Longley, \& Prescott, 1999). These tasks have been specifically designed and validated for use with children between 36 to 50 months of age. Because the children in the present study were 33 months old, we reduced the duration of the anger tasks to 2 min and the joy tasks to $1 \mathrm{~min}$. The anger-joy tasks were presented to children in pairs.

For the first pair, children participated in (a) the attractive toy in container task (Children are asked to use a key to get the toy out of a locked, clear container.), followed immediately by (b) the popping bubbles task (Bubbles are sent into the air from a toy, and children are instructed to pop as many bubbles that they can.) After this pair, children were given a 30-s or longer break to return to emotional baseline. For the second pair, children participated in (c) the draw a perfect green line task. Children are 
given a sheet of paper and a green marker and asked to draw an impossibly perfect, green line. An adult working with the child will give sensitive feedback, asking the child to try again. The original task was modified from drawing a circle to drawing a line because the children in our study were 3 months shy of the 36-month age for which the task was developed. Immediately following the draw a perfect line task, children participated in the final (d) tickle the bunny task, which was used to induce joy (Conway, 2005). Children were asked to tickle a toy bunny and to make the bunny laugh. Children were videotaped while participating in these tasks, which were subsequently coded by trained, undergraduate research assistants.

\section{Coding/Data Reduction}

EC. EC was based on assessments of persistence. Trained research assistants rated the child's persistence during the 33-month visit for all tasks except for the emotion tasks. Adapted from the NICHD Early Child Care and Youth Development Study (2005), child persistence ratings reflected the degree to which the child sustained long periods of attention, and involvement in the activities was rated on a scale of 1 (very low) to 5 (very high). Children scoring low on persistence may refuse involvement, engage in off-task activities and behaviors, and be easily distracted, inattentive, or distracted. Children scoring very high may be actively engaged with the task and actively persists. Coders met for extensive training and supervision with a master coder. Reliability was calculated on $20 \%$ of the tapes, and the average reliability score (weighted $\kappa$ ) was .58.

Emotional-expression coding. Trained undergraduate research assistants coded children's emotional expression at 33 months during the four emotion-induction tasks. Facial and voice-quality cues developed by Cole, Barrett, and Zahn-Waxler (1992) were used to determine the presence of anger, sadness, and joy coded continuously on a second-by-second basis. Coders were trained extensively and supervised by a primary coder. Consensus meetings were held to resolve trainees' questions. Two students, one for each anger-joy pair, coded the data. To reduce coder bias, each student coded one pair of anger-joy tasks and was not allowed to code the second pair. Coders continued training until agreement was reached on $20 \%$ of randomly selected tapes. Percent agreement ranged from .71 to .99 .

The proportion of time that children expressed anger, sadness, and joy was calculated for each child. This produced three outcome scores for each child-anger, sadness, and joy-for all four emotion tasks. As expected, more anger and sadness were expressed during the container and line tasks whereas more joy was expressed during the bubble and bunny tasks, $p<.05$ (Table 1). No gender differences were observed.

Latency to positive emotion following challenge. The total number of seconds until children expressed joy following the challenge tasks was calculated, and log transformations were used to correct for skewness. Latencies to joy expression in the bubble and bunny
TABLE 1. Mean Proportion of Emotions Expressed During Emotion Tasks

\begin{tabular}{|c|c|c|c|c|c|}
\hline Emotion & $\begin{array}{c}\text { Container } \\
(120 \mathrm{~s})\end{array}$ & $\begin{array}{l}\text { Line } \\
(120 \mathrm{~s})\end{array}$ & $\begin{array}{c}\text { Bubble } \\
(60 \mathrm{~s})\end{array}$ & $\begin{array}{l}\text { Bunny } \\
(60 \mathrm{~s})\end{array}$ & $\begin{array}{c}F \\
(1,154)\end{array}$ \\
\hline Anger & $0.32(0.27)^{\mathrm{ab}}$ & $0.16(0.18)^{\mathrm{ab}}$ & $0.02(0.06)^{\mathrm{ac}}$ & $0.03(0.08)^{\mathrm{ac}}$ & $115.01^{* * *}$ \\
\hline Sadness & $0.14(0.25)^{\mathrm{ab}}$ & $0.04(0.12)^{\mathrm{ab}}$ & $0.01(0.07)^{\mathrm{ac}}$ & $0.02(0.10)^{\mathrm{ac}}$ & $26.39^{* * *}$ \\
\hline Joy & $0.30(0.10)^{\mathrm{ab}}$ & $0.20(0.24)^{\mathrm{ab}}$ & $0.55(0.36)^{\mathrm{a}}$ & $0.83(0.33)^{\mathrm{a}}$ & $291.43^{* * *}$ \\
\hline
\end{tabular}

Note. Numbers in parenthesis are $S D$ s.

${ }^{*} p<.01,{ }^{*} p<.05$. Means in the same row that share superscripts differ at $p<.05$.

tasks were significantly correlated, $r=.23, p<.01$, and scores were standardized and averaged to create a composite score used in all analyses. Longer latency to positive emotion was associated with (a) more sadness in the bubble task, $r=.35, p<.001$, and (b) more anger in the bubble task, $r=.14, p<.09$, and the bunny task, $r=.18, p<.05$, and (c) less joy in the bubble task, $r=-.38$, $p<.001$, the line task, $r=-.24, p<.01$, and the bunny task, $r=$ $-.46, p<.001$.

\section{RESULTS}

\section{Descriptive Information and Correlations}

Relations between demographic and outcome variables were assessed. Specifically, we tested differences in EC and latency to positive emotions based on child sex, child race/ethnicity, maternal education, marital status, and family income. No differences were revealed. Maternal age, however, was significantly associated with shorter latency to positive emotion. Therefore, maternal age was included as a covariate in all analyses.

Tables 2 and 3 present descriptive statistics and correlations, respectively. Maternal sensitivity variables were significantly

TABLE 2. Descriptive Data for Measures in Model Testing

\begin{tabular}{|c|c|c|c|}
\hline \multirow[b]{2}{*}{ Variable } & \multirow[b]{2}{*}{$M$} & \multicolumn{2}{|c|}{ Range } \\
\hline & & Possible & Observed \\
\hline \multicolumn{4}{|l|}{ Maternal Sensitivity at 7 Months } \\
\hline 1. Free Play & $2.32(0.64)$ & $0-3$ & $1-3$ \\
\hline 2. Teaching Task & $2.35(0.69)$ & $0-3$ & $0-3$ \\
\hline 3. High Chair Interaction & $2.04(0.79)$ & $0-3$ & $0-3$ \\
\hline \multicolumn{4}{|l|}{ Infant Affect at 7 Months } \\
\hline 4. Negative Affect Still-Face & $1.51(1.14)$ & $0-3$ & $0-3$ \\
\hline \multicolumn{4}{|l|}{ Effortful Control at 33 Months } \\
\hline 5. Persistence & $3.25(0.90)$ & $1-5$ & $2-5$ \\
\hline \multicolumn{3}{|c|}{ Emotion Regulation/Latency to Positive Emotions } & \\
\hline 6. Latency to Positive Emotions & $7.58(10.74)^{\mathrm{a}}$ & $1-60$ & $1-60$ \\
\hline \multicolumn{4}{|l|}{ Controls } \\
\hline 7. Maternal Age & $29.93(5.143)$ & $16-43$ & $16-43$ \\
\hline 8. Infant Positive Affect Face Play & $0.87(0.79)$ & $0-3$ & $0-3$ \\
\hline
\end{tabular}

Note. Numbers in parentheses are SDs. ${ }^{\text {a }}$ Total number of seconds. 
TABLE 3. Correlation Matrix of Variables Included in Model Testing

\begin{tabular}{|c|c|c|c|c|c|c|c|}
\hline Variables & 1 & 2 & 3 & 4 & 5 & 6 & 78 \\
\hline \multicolumn{8}{|l|}{ Maternal Sensitivity at 7 Months } \\
\hline 1. Free Play & - & & & & & & \\
\hline 2. High Chair Interaction & $.34^{* * *}$ & - & & & & & \\
\hline 3. Teaching Task & $.34^{* * *}$ & $.21^{* *}$ & - & & & & \\
\hline \multicolumn{8}{|l|}{ Infant Affect at 7 Months } \\
\hline 4. Negative Affect & -.07 & $-.19^{* *}$ & -.12 & - & & & \\
\hline \multicolumn{8}{|l|}{ Effortful Control at 33 months } \\
\hline 5. Persistence & .13 & $.22^{* *}$ & .06 & .04 & - & & \\
\hline \multicolumn{8}{|c|}{$\begin{array}{l}\text { Emotion Regulation/Latency to Positive Emotion } \\
\text { Following Challenge at } 33 \text { Months }\end{array}$} \\
\hline 6. Latency to Positive Emotions & $s-.18^{*}$ & -.06 & $-.16^{*}$ & $-.02-$ & $-.23^{* *}$ & - & \\
\hline \multicolumn{8}{|l|}{ Controls } \\
\hline 7. Maternal Age & $.17^{* *}$ & $.24^{* *}$ & $.25^{* * *}$ & .00 & .10 & $-.20^{* *}$ & - \\
\hline 8. Infant Positive Affect & .09 & -.04 & .08 & $.00-$ & -.08 & -.10 & -.06 \\
\hline
\end{tabular}

Note. ${ }^{*} p<.05,{ }^{* *} p<.01,{ }^{* * *} p<.001$.

correlated and were associated with infant/child variables. Maternal sensitivity during the high chair free-play task was significantly associated with higher EC and negatively associated with infant negative affect. Maternal sensitivity during the free-play task was marginally associated with shorter latency to positive emotion. EC predicted shorter latency to positive emotion. Finally, maternal age was associated with higher levels of sensitivity during the freeplay, high chair, and teaching tasks and shorter latency to positive emotion.

\section{Measurement Model}

Confirmatory factor analysis was used to examine the factor structure for measures of maternal sensitivity. The latent factor for maternal sensitivity was indicated by maternal sensitivity demonstrated during the free-play, teaching, and high chair free-play tasks. Maternal age was included a covariate since it was significantly associated with the outcome variables of the structural model and will be used in the structural model. Infant positive affect also was included as a covariate since it will be used as a covariate in the structural equation model. The measurement model was a good fit to the data, $\chi^{2}(4, N=156)=6.26, p<.18$, Tucker-Lewis index $(\mathrm{TLI})=.89$, comparative fit index $(\mathrm{CFI})=.96$, and root mean square error $($ RMSEA $)=.06$. Findings indicate that the manifest variables were related to the latent variable, as hypothesized (The measurement model and parameter estimates are not shown but are available upon request).

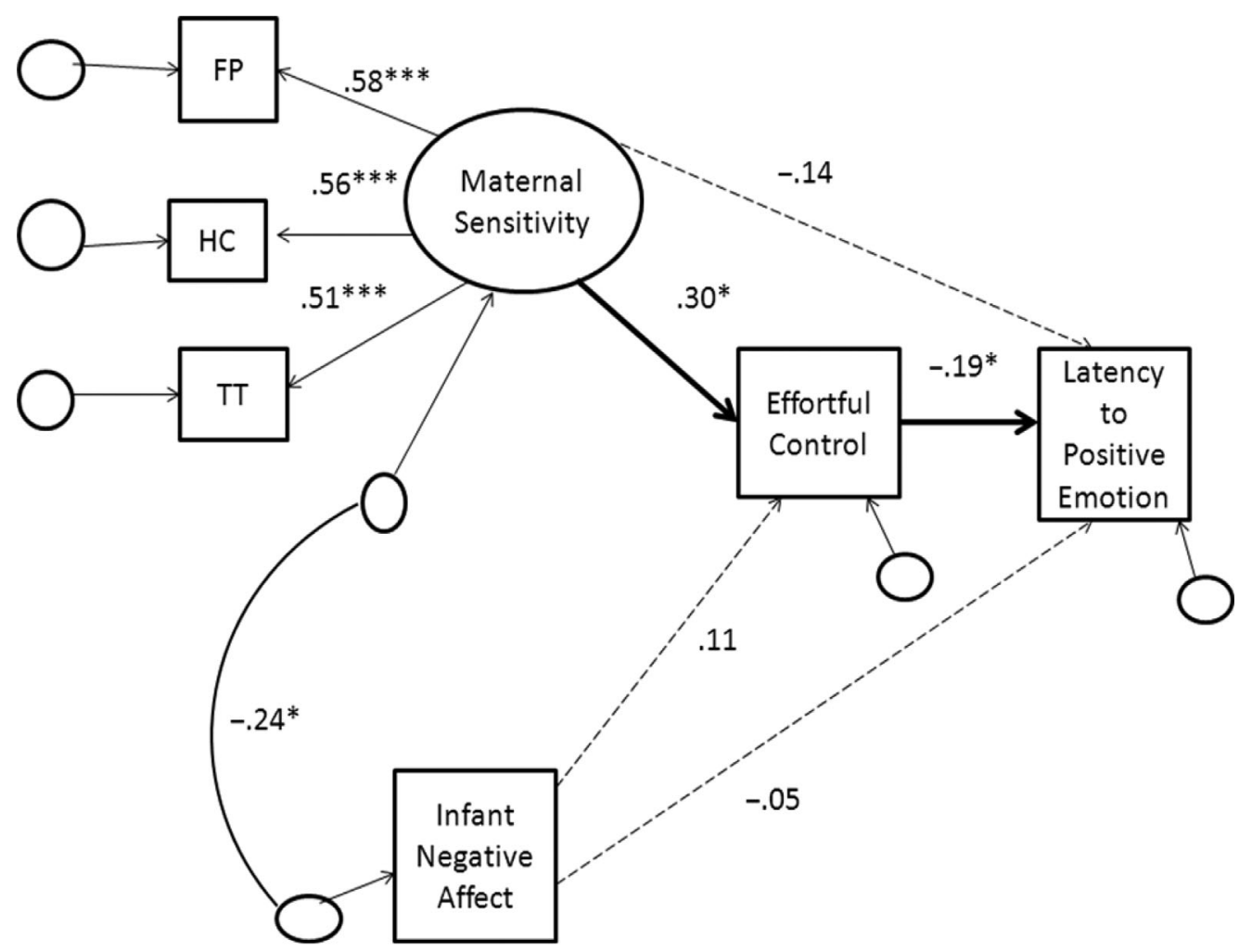

FIGURE 1. Longitudinal structural model with standardized estimates. Covariates include maternal age and infant positive affect. $\chi^{2}(10, N=181)=14.13, p<.17$, Tucker-Lewis index $(\mathrm{TLI})=.840$, comparative fit index $(\mathrm{CFI})=.943$, root mean square error $(\mathrm{RMSEA})=.05, \mathrm{FP}=$ Free Play; HC $=$ High Chair Interaction; TT $=$ Teaching Task. 
TABLE 4. Summary Direct, Total, and Indirect Effects of Maternal Sensitivity and Infant Negative Affect at 7 Months to Latency of Positive Emotions at 33 Months

\begin{tabular}{lccc}
\hline & \multicolumn{1}{c}{ Direct } & Total & Indirect \\
\hline IV $\rightarrow$ Latency to Positive Emotions & & \\
Maternal Sensitivity & $-0.310(0.468)$ & $-0.436(0.400)$ & $-0.126(0.187)^{*}$ \\
Infant Negative Affect & $-0.031(0.065)$ & $-0.045(0.062)$ & $-0.015(0.015)$ \\
\hline
\end{tabular}

Note. IV $=$ Independent variable.

$* p<.05$.

\section{Structural Equation Modeling (SEM)}

SEM was used to test the longitudinal hypothesis that maternal sensitivity and infant negative affect predicted EC, which in turn predicts shorter latency to positive emotions using Amos 21.0 (Arbuckle, 2012). Because maternal age was significantly associated with maternal sensitivity and latency to positive emotion, maternal age was included in the model as a covariate. Infant positive affect at 7 months also was included as a covariate to control for prior levels of positive affectivity. Maternal sensitivity, infant affect (both positive and negative), and maternal age were allowed to correlate.

The model provided a good fit to the data, $\chi^{2}(10, N=156)=$ $14.13, p<.17, \mathrm{TLI}=.84, \mathrm{CFI}=.94, \mathrm{RMSEA}=.05$ (Figure 1 ; also see the Appendix 1). Results indicate a significant indirect effect of maternal sensitivity at 7 months on latency to positive emotion at 33 months. This indirect effect was offset, however, by a (nonsignificant) direct effect, resulting in a nonsignificant total effect.

The SEM model revealed no significant direct paths between maternal sensitivity and infant negative affect at 7 months and latency to positive emotions at 33 months. However, indirect effects were significant, indicating that maternal sensitivity, but not infant negative affect, significantly predicted higher EC, which in turn significantly predicted shorter latency to positive emotion following challenge (Figure 1). In other words, children whose mothers demonstrated more sensitivity at 7 months evidenced higher levels of EC at 33 months. In turn, higher levels of EC were significantly associated with shorter latency to positive emotion at 33 months. These findings suggest that the indirect effects of maternal sensitivity at 7 months and latency to positive emotion at 33 months operate through effects on EC (Table 4).

The indirect effect of $\mathrm{EC}$ on the relation between maternal sensitivity and latency to positive emotion was tested with bootstrap methods (MacKinnon, Lockwood, \& Williams, 2004). With the number of bootstrap resamples $=250$, the mean indirect effect was $-.126, p=.03$, which fell between a $90 \%$ confidence interval of -.624 and -.025 . Statistical significance of the indirect effect was reflected in the lack of inclusion of zero in the confidence interval. $^{1}$

\footnotetext{
${ }^{1}$ Because EC and latency to positive emotions were measured concurrently, we checked the alternative reverse model. Results showed that latency to positive
}

\section{DISCUSSION}

As a new contribution to research, we examined the early antecedents and predictors of the ability to self-generate positive emotions following challenge-An important aspect of emotion regulation. We hypothesized that higher levels of maternal sensitivity and lower levels of infant negative affect during the first year of life would predict higher levels of EC and that this in turn would predict shorter latencies to positive emotions following challenge. Results provide support for our hypothesized model. Maternal sensitivity at 7 months, but not infant negative affect, predicted better EC, which in turn was associated with shorter latencies to positive emotions following challenge at 33 months. We believe that this is the first study to document these relations. In the following sections, we discuss the findings.

Studies have begun to address children's expressions of positive emotions following challenge as an important aspect of emotion regulation, but significantly less attention has been placed on examining early antecedents and underlying mechanisms and pathways that forecast the development of this ability. Our findings linking maternal sensitivity and EC in early childhood support theory for the role of environmental influences on the development of EC (Rothbart \& Bates, 2006). They are also consistent with a growing research base illustrating relations between aspects of parenting such as maternal sensitivity, positivity, and support and later EC (Eisenberg et al., 2005; Kochanska \& Murray, 2000; Kochanska et al., 2000; NICHD Early Child Care Research Network, 1998; Spinrad et al., 2012). In particular, our findings of higher levels of maternal sensitivity at 7 months predicting higher levels of EC are consistent with existing studies and extend this work to demonstrate that maternal sensitivity during the first year of life forecasts better EC 2 years later.

With respect to relations between EC and latency to positive emotions following challenge, a few studies previously have demonstrated relations in older children (Eisenberg et al., 2003; Kieras et al., 2005; Simonds et al., 2007). Our findings are consistent with prior work and extend it by reporting that EC is an important link in the pathway from maternal sensitivity during infancy and this component of emotion regulation at 33 months.

Indeed, our findings also support theory proposed by Posner and Rothbart (2000) that EC plays an important role in facilitating emotional processes and regulation, and suggest that children's development in EC abilities provides the attentional and cognitive foundation from which children can capitalize on in the service of generating and regulating emotions. Through repeated and early experiences of development within the context of sensitivity, infants over time may strengthen their emerging executive attention and EC abilities. It is these abilities that may underlie their ability to flexibly self-generate and regulate positive emotions-even

emotions following challenge did not mediate relations between maternal sensitivity, infant negative affect, and EC. Results are available upon request. 
after challenge. In sum, although direct effects were not significant, indirect effects were found such that maternal sensitivity at 7 months predicted higher levels of EC, and this was associated with shorter latencies to positive emotions following challenge at 33 months.

Interestingly, infant negative affect was not associated with children's EC and latency to positive emotions following challenge. We also controlled for infant positive affect, and it also was not associated with EC or latency to positive emotions following challenge. Although this was unexpected, the lack of associations between infant negative and positive affect and subsequent EC may be because these are two different temperament systems. For example, it is possible that infant positive affect reflects the reactive component of temperament, or more specifically, exuberance and high approach based on Gray's (1991) behavioral approach system. Temperamental reactivity and EC are separate systems with distinct neural pathways and have been found to make independent contributions to child behavioral outcomes (Eisenberg et al., 2004; Rothbart \& Posner, 2006). This may be particularly true of relations between reactivity during infancy and later EC, which undergoes significant development during toddlerhood. Therefore, these systems may not be strongly related at different points of development.

The lack of associations between early infant positive affect and 33-month latency to positive affect also may be because they are tapping different underlying emotional constructs. Indeed, the former may reflect positive affectivity whereas the latter may reflect emotion regulation, and these may be distinct. Likewise, latency to positive emotions following challenge actually may be an index of the larger construct of emotional resilience, or egoresiliency, which is commonly studied and measured in the adult literature reflecting one's ability to emotionally recover following stress and challenge (Fredrickson, Mancuso, Branigan, \& Tugade, 2000).

Strengths of the study include the use of a longitudinal design, multiple observational measures, and SEM. SEM allowed for control of measurement error and simultaneous tests of longitudinal effects. Furthermore, the study design provided a unique opportunity to assess emotional expressions and emotion regulation on a second-by-second basis. Observational assessments of EC components such as persistence, which have received considerable attention in EC research, also were used (Eisenberg et al., 2003; Kochanska \& Murray, 2000). This study expands on existing research by examining these relations in (a) 33-month-old children, (b) boys and girls, and (c) a large sample.

Despite the strengths, there are a number of limitations. For example, although we used emotion tasks that have been wellvalidated for children between the ages of 36 to 50 months, the children in the study were only 33 months. Although the children in this study were just 3 months shy of 36 months, caution is needed in interpreting these findings. Another limitation is that EC and latency to positive emotions were assessed concurrently, and it is possible that latency to positive emotion mediates the relations between maternal sensitivity and EC. As a check, we tested this alternative model; the results showed that latency to positive emotions did not mediate relations between maternal sensitivity and EC (results are available upon request).

Also note that findings from the study may not generalize to children across different cultures and contexts. Significant cultural differences exist in cultural beliefs and norms about appropriate expressions of emotions. For example, although maximizing positive emotions may be a cultural goal in Western contexts, moderated positive and negative emotions may be a cultural goal in Asian contexts (Leu, Wang, \& Koo, 2011). Indeed, low-arousal positive emotions may be preferred by East Asians whereas high-arousal positive emotions may be preferred by European Americans (Tsai, 2007). Therefore, latency to positive emotion following challenge, along with antecedents and underlying mechanisms, may vary across different cultural contexts and must be taken into consideration for future research and interventions.

In future research, it also will be important to examine whether latency to positive emotions is an early marker or correlate of competent or problematic developmental outcomes and trajectories. Indeed, young children's ability to self-generate positive emotion following disappointment has been associated with low levels of behavior problems (Cole, Zahn-Waxler, \& Smith, 1994). Likewise, in adults, findings have indicated that expressions of positive emotions following stress and challenge are associated with positive adaptation following loss (Bonanno \& Keltner, 1997), positive adjustment following the September 11, 2001 attacks on the World Trade Center and the Pentagon (Fredrickson, Tugade, Waugh, \& Larkin, 2003), and faster cardiovascular recovery following stress (Fredrickson \& Levenson, 1998; Fredrickson et al., 2000). Little observational research, however, has examined this form of emotional resilience and the longitudinal and concurrent behavioral correlates in early childhood. It is possible that our observational assessment of latency to positive emotions overlaps with rating assessments of ego-resiliency used in the Eisenberg et al. $(2003,2004)$ studies and may be an important direction for future research.

In summary, findings from this study may have important implications for infant mental health prevention and intervention. Like the related constructs of emotion regulation and egoresiliency, the ability to flexibly transition across changing contexts and generate positive emotions following challenge is predicted by early experiences of maternal sensitivity and EC. This suggests that maternal sensitivity and EC are important starting points in this developmental pathway and should be considered in preventive interventions in infant mental health. Although more research is needed, interventions designed to enhance maternal sensitivity and EC may have important effects on the development of children's emotional functioning-particularly positive emotional functioning. 


\section{APPENDIX}

Unstandardized and Standardized Estimates for Model in Figure 1 (SEs in parentheses; $N=156$ )

\begin{tabular}{|c|c|c|}
\hline Structural Model Estimates & Unstandardized & Standardized \\
\hline Maternal Sensitivity $\rightarrow$ Persistence & $.77(.36)^{*}$ & $.30^{*}$ \\
\hline $\begin{array}{l}\text { Maternal Sensitivity } \rightarrow \text { Latency to Positive } \\
\text { Emotions }\end{array}$ & $-.31(.29)$ & -.14 \\
\hline $\begin{array}{l}\text { Persistence } \rightarrow \text { Latency to Positive } \\
\text { Emotions }\end{array}$ & $-.16(.07)^{*}$ & $-.19^{*}$ \\
\hline Infant Negative Affect $\rightarrow$ Persistence & $.09(.07)$ & .11 \\
\hline $\begin{array}{l}\text { Infant Negative Affect } \rightarrow \text { Latency to } \\
\text { Positive Emotions }\end{array}$ & $-.03(.06)$ & -.05 \\
\hline $\begin{array}{l}\text { Covariance Maternal Sensitivity and Infant } \\
\text { Negative Affect }\end{array}$ & $-.09(.05)^{*}$ & $-.23^{*}$ \\
\hline \multicolumn{3}{|l|}{ (Control Variables) } \\
\hline Maternal Age and Persistence & $-.01(.02)$ & -.03 \\
\hline $\begin{array}{l}\text { Maternal Age and Latency to Positive } \\
\text { Emotions }\end{array}$ & $-.02(.01)$ & -.13 \\
\hline Infant Positive Affect and Persistence & $-.12(.09)$ & -.11 \\
\hline $\begin{array}{l}\text { Infant Positive Affect and Latency to } \\
\text { Positive Emotions }\end{array}$ & $-.11(.08)$ & -.12 \\
\hline $\begin{array}{l}\text { Covariance Maternal Age and Maternal } \\
\text { Sensitivity }\end{array}$ & $.71(.23)^{*}$ & $.39^{*}$ \\
\hline $\begin{array}{l}\text { Covariance Maternal Age and Infant } \\
\text { Negative Affect }\end{array}$ & $.04(.47)$ & .01 \\
\hline $\begin{array}{l}\text { Covariance Maternal Age and Infant } \\
\text { Positive Affect }\end{array}$ & $-.26(.33)$ & -.06 \\
\hline $\begin{array}{l}\text { Covariance Infant Positive Affect and } \\
\text { Maternal Sensitivity }\end{array}$ & $.02(.03)$ & .08 \\
\hline $\begin{array}{l}\text { Covariance Infant Positive Affect and } \\
\text { Infant Negative Affect }\end{array}$ & $.00(.07)$ & .00 \\
\hline
\end{tabular}

Note. Model controls for maternal age and infant positive affect. $\chi^{2}(10, N=$ $156)=14.13, p<.17$, Tucker-Lewis index $=.84$, comparative fit index $=.94$, root mean square error $=.05$. $* p<.05, * * p<.01, * * * p<.001$.

\section{REFERENCES}

Arbuckle, J.L. (2012). Amos (Version 21.0). Chicago: SPSS.

Arend, R., Gove, F.L., \& Sroufe, L.A. (1979). Continuity of individual adaptation from infancy to kindergarten: A predictive study of egoresiliency and curiosity in preschoolers. Child Development, 50, 950959.

Block, J.H., \& Block, J. (1980). The role of ego-control and ego-resiliency in the organization of behavior. In W.A. Collins (Ed.), Minnesota Symposia on Child Psychology (Vol. 13, pp. 39-101). Hillsdale, NJ: Erlbaum.

Bonanno, D., \& Keltner, D. (1997). Facial expressions of emotion and the course of conjugal bereavement. Journal of Abnormal Psychology, 106, 126-137.

Braungart-Rieker, J., \& Stifter, C.A. (1996). Infants' responses to frustrating situations: Continuity and change in reactivity and regulation. Child Development, 67, 1767-1779.

Braungart-Rieker, J.M., Garwood, M.M., Powers, B.P., \& Notaro, P.C. (1998). Infant affect and affect-regulation during the still-face paradigm with mothers and fathers: The role of infant characteristics and parental sensitivity. Developmental Psychology, 34, 1428-1437.

Calkins, S.D. (1994). Origins and outcomes of individual differences in emotion regulation. In N.A. Fox (Ed.), The development of emotion regulation: Behavioral and biological considerations (Vol. 59, pp. 53-72). Chicago: University of Chicago Press.

Clark, C.A., Woodward, L.J., Horward, L.J., \& Moor, S. (2008). Development of emotional and behavioral regulation in children born extremely preterm and very preterm: Biological and social influences. Child Development, 79, 1444-1462.

Cohn, J.F., \& Tronick, E.Z. (1983). Three-month-old infants' reaction to simulated maternal depression. Child Development, 54, 185-193.

Cole, P.M., Barrett, K.C., \& Zahn-Waxler, C. (1992). Emotion displays in two-year-olds during mishaps. Child Development, 63, 314-324.

Cole, P.M., Zahn-Waxler, C., \& Smith, K.D. (1994). Expressive control during a disappointment: Variations related to preschoolers' behavior problems. Developmental Psychology, 30, 835-846.

Conway, A. (2005). The development of emotion regulation: The role of effortful attentional control and positive affect. Unpublished doctoral dissertation, University of Michigan, Ann Arbor.

Crowell, J.A., \& Feldman, S.S. (1988). Mother's internal working models of relationships and children's behavioral and developmental status: A study of mother-child interaction. Child Development, 59, 12731285 .

Dennis, T. (2006). Emotional self-regulation in preschoolers: The interplay of child approach reactivity, parenting, and control capacities. Developmental Psychology, 42, 84-97.

Drake, K., Belsky, J., \& Fearon, R.M. (2013, May 6). From early attachment to engagement with learning in school: The role of selfregulation and persistence. Developmental Psychology [Epub].

Eisenberg, N., Guthrie, I.K., Fabes, R.A., Reiser, M., Murphy, B.C., Holgren, R. et al. (1997). The relations of regulation and emotionality to resiliency and competent functioning in elementary school children. Child Development, 68, 295-311.

Eisenberg, N., Spinrad, T.L., Fabes, R.A., Reiser, M., Cumberland, A., Shepard, S.A. et al. (2004). The relations of effortful control and impulsivity to children's resiliency and adjustment. Child Development, 75(1), 25-46.

Eisenberg, N., Valiente, C., Fabes, R.A., Smith, C.L., Reiser, M., Shepard, S.A. et al. (2003). The relations of effortful control and ego control to children's resiliency and social functioning. Developmental Psychology, 39(4), 761-776.

Eisenberg, N., Zhou, Q., Spinrad, T.L., Valiente, C., Fabes, R.A., \& Liew, J. (2005). Relations among positive parenting, children's effortful control, and externalizing problems: A three-wave longitudinal study. Child Development, 76, 1055-1071.

Field, T. (1981). Infant gaze aversion and heart rate during face-to-face interactions. Infant Behavior \& Development, 4, 307-315.

Field, T. (1994). The effects of mother's physical and emotional unavailability on emotion regulation. In N.A. Fox (Ed.), The development of emotion regulation: Biological and behavioral considerations. Monographs of the Society for Research in Child Development, (Vol. 59; Serial No. 240, pp. 208-227). Chicago: University of Chicago Press. 
Fredrickson, B.L., \& Levenson, R.W. (1998). Positive emotions speed recovery from the cardiovascular sequelae of negative emotions. Cognition \& Emotion, 12, 191-220.

Fredrickson, B.L., Mancuso, R.A., Branigan, C., \& Tugade, M.M. (2000). The undoing effect of positive emotions. Motivation \& Emotion, 24, 237-258.

Fredrickson, B.L., Tugade, M.M., Waugh, C.E., \& Larkin, G.R. (2003). What good are positive emotions in crises? A prospective study of resilience and emotions following the terrorist attacks on the United States on September 11th, 2001. Journal of Personality \& Social Psychology, 84, 365-376.

Gable, S., \& Isabella, R.A. (1992). Maternal contributions to infant regulation of arousal. Infant Behavior \& Development, 15, 95-107.

Gilliom, M., Shaw, D., Beck, J.E., Schonberg, M.A., \& Lukon, J.L. (2002). Anger regulation in disadvantaged preschool boys: Strategies, antecedents, and the development of self-control. Developmental Psychology, 38(2), 222-235.

Goldsmith, H.H., Buss, K.A., \& Lemery, K.S. (1997). Toddler and childhood temperament: Expanded content, stronger genetic evidence, new evidence for the importance of environment. Developmental Psychology, 33, 891-905.

Goldsmith, H.H., Reilly, J., Lemery, S., Longley, S., \& Prescott, A. (1999). The laboratory temperament assessment battery: Preschool version. Unpublished manuscript.

Gray, J.A. (1991). Neural systems, emotion and personality. In J.I.V. Madden (Eds.), Neurobiology of learning, emotion and affect (pp. 273-306). New York: Raven Press.

Graziano, P.A., Keane, S.P., \& Calkins, S.D. (2010). Maternal behavior and children's early emotion regulation skills differentially predict development of children's reactive control and later effortful control. Infant \& Child Development, 19, 333-353.

Haley, D.W., \& Stansbury, K. (2003). Infant stress and parent responsiveness: Regulation of physiology and behavior during the still-face and reunion. Child Development, 74, 1534-1546.

Kieras, J.E., Tobin, R.M., Graziano, W.G., \& Rothbart, M.K. (2005). You can't always get what you want: Effortful control and children's responses to undesirable gifts. Psychological Science, 16(5), 391396.

Kochanska, G., \& Murray, K.T. (2000). Mother-child mutually responsive orientation and conscience development: From toddler to early school age. Child Development, 71, 417-431.

Kochanska, G., Murray, K.T., \& Harlan, E.T. (2000). Effortful control in early childhood: Continuity and change, antecedents, and implications for social development. Developmental Psychology, 36, 220-232.

Kogan, N., \& Carter, A.S. (1996). Mother-infant reengagement following the still-face: The role of maternal emotional availability in infant affect regulation. Infant Behavior \& Development, 19, 359-370.

Kopp, C.B. (1989). Regulation of distress and negative emotions: A developmental review. Developmental Psychology, 25, 343-354.

Kopp, C.B. (1992). Emotional distress and control in young children. In N. Eisenberg \& R.A. Fabes (Eds.), Emotion and its regulation in early development (pp. 41-56). New Directions for Child Development, no. 55. San Francisco: Jossey-Bass.

Leerkes, E.M., Blankson, N., \& O’Brien, M. (2009). Differential effects of maternal sensitivity to infant distress and nondistress on socialemotional functioning. Child Development, 80, 762-775.

Leu, J., Wang, J., \& Koo, K. (2011). Are positive emotions just as "positive" across cultures? Emotion, 11, 994-999.

Liew, J., Eisenberg, N., Losoya, S.H., Fabes, R.A., Guthrie, I.K., \& Murphy, B.C. (2003). Children's physiological indices of empathy and their socioemotional adjustment: Does caregivers' expressivity matter? Journal of Family Psychology, 17, 584-597.

Li-Grining, C.P. (2007). Effortful control among low-income preschoolers in three cities: Stability, change, and individual differences. Developmental Psychology, 4, 208-221.

MacKinnon, D.P., Lockwood, C.M., \& Williams, J. (2004). Confidence limits for the indirect effect: Distribution of the product and resampling methods. Multivariate Behavioral Research, 39, 99-128.

Mangelsdorf, S.C., Shapiro, J.R., \& Marzolf, D. (1995). Developmental and temperamental differences in emotion regulation in infancy. Child Development, 66, 1817-1828.

McDonough, S.C. (1994). Preventing mental health problems in multirisk infants. National Institute of Mental Health RO1 Grant Proposal, University of Michigan, Ann Arbor.

Miller, A.L., McDonough, S.C., Rosenblum, K.R., \& Sameroff, A.J. (2002). Emotion regulation in context: Situational effects on infant and caregiver behavior. Infancy, 4, 403-433.

Nachmias, M., Gunnar, M., Mangelsdorf, S., Parritz, R.H., \& Buss, K. (1996). Behavioral inhibition and stress reactivity: The moderating role of attachment security. Child Development, 67, 508-522.

NICHD Early Child Care Research Network. (1998). Early child care and self-control, compliance, and problem behavior at 24 and 36 months. Child Development, 69(3), 1145-1170.

NICHD Early Child Care Research Network. (2005). Early child care and children's development in the primary grades: Follow-up results from the NICHD Study of Early Child Care. American Educational Research Journal, 42(3), 537-570.

Olson, S.L., Bates, J.E., \& Bayles, K. (1990). Early antecedents of childhood impulsivity: The role of parent-child interaction, cognitive competence, and temperament. Journal of Abnormal Child Psychology, 18, 317-334.

Olson, S.L., Bates, J.E., Sandy, J.M., \& Schilling, E.M. (2002). Early developmental precursors of impulsive and inattentive behavior: From infancy to middle childhood. Journal of Child Psychology \& Psychiatry, 43, 435-447.

Posner, M.I., \& Rothbart, M.K. (2000). Developing mechanisms of selfregulation. Development and Psychopathology, 12(3), 427-441.

Rosenblum, K., McDonough, S., Muzik, M., Miller, A., \& Sameroff, A. (2002). Maternal representations of the infant: Associations with infant response to the still face. Child Development, 73, 9991015 .

Rothbart, M.K. (1989). Temperament in childhood: A framework. In G. Kohnstamm, J. Bates, \& M.K. Rothbart (Eds.), Temperament in childhood (pp. 59-73). Chichester, England: Wiley. 
Rothbart, M.K., \& Bates, J.E. (2006). Temperament. In W. Damon \& N. Eisenberg (Eds.), Handbook of child psychology: Vol. 3. Social, emotional, and peronsality development (6th ed., pp. 99-176). New York: Wiley.

Rothbart, M.K., Ellis, L.K., Rueda, M.R., \& Posner, M.I. (2003). Developing mechanisms of temperamental effortful control. Journal of Personality, 71, 1113-1143.

Rothbart, M.K., \& Posner, M.I. (2006). Temperament, attention, and developmental psychopathology. In D. Cicchetti \& D.J. Cohen (Eds.), Developmental psychopathology, Vol. 2, Developmental Neuroscience (2nd ed.). Hoboken, NJ: Wiley.

Seifer, R., Dickstein, S., Parade, S.H., Hayden, L.C., Magee, K.D., \& Schiller, M. (2014). Mothers' appraisal of goodness of fit and children's social development. International Journal of Behavioral Development, 38, 86-97.

Silverman, I.W., \& Ragusa, D.M. (1990). Child and maternal correlates of impulse control in 24-month-old children. Genetic, Social, and Psychology Monographs, 116, 435-473.

Simonds, J., Kieras, J.E., Rueda, M.R., \& Rothbart, M.K. (2007). Effortful control, executive attention, and emotional regulation in 7-10-yearold children. Cognitive Development, 22, 474-488.

Spinrad, T.L., Eisenberg, N., Silva, K.M., Eggum, N.D., Reiser, M., Edwards, A. et al. (2012). Longitudinal relations among maternal behav- iors, effortful control and young children's committed compliance. Developmental Psychology, 48, 552-566.

Stifter, C.A., \& Moyer, D. (1991). The regulation of positive affect: Gaze aversion activity during mother-infant interaction. Infant Behavior \& Development, 14, 111-123.

Taylor, Z.E., Eisenberg, N., Spinrad, T.L., \& Widaman, K.F. (2013). Longitudinal relations of intrusive parenting and effortful control to egoresiliency during early childhood. Child Development, 84, 11451151.

Thompson, R.A., \& Lamb, M.L. (1984). Qualitative dimensions of emotional responsiveness in infants: Separation reactions in the strange situation. Infant Behavior \& Development, 7, 423-445.

Tronick, E.Z., \& Weinberg, M.K. (1992, November). Manual for the face-to-face still-face paradigm. Boston: Children's Hospital, Harvard University Medical School.

Tsai, J.L. (2007). Ideal affect: Cultural causes and behavioral consequences. Perspectives on Psychological Science, 2, 242-259.

Vygotsky, L.S. (1981). The genesis of higher mental functions. In J.V. Wertsch (Ed.), The concept of activity in Soviet psychology (pp. 144-188). New York: Sharpe.

Weinberg, M.K., \& Tronick, E.Z. (1996). Infant affective reactions to the resumption of maternal interaction after the still-face. Child Development, 67, 905-914. 